Revista Brasileira de Agricultura Irrigada v.14, nº.1, p. 3875 - 3888, 2020

ISSN 1982-7679 (On-line)

Fortaleza, CE, INOVAGRI - http://www.inovagri.org.br

DOI: $10.7127 /$ rbai.v14n1001103

Protocolo 1103.20 - 31/07/2019 Aprovado em 18/05/2020

\title{
INDICATORS AND CRITERIA TO DEFINE THE PRIORITY FOR IRRIGATION WATER USE IN THE BAIXO JAGUARIBE BASIN, BRAZIL
}

José Antônio Frizzone ${ }^{1}$, Sílvio Carlos Ribeiro Vieira Lima², Débora Costa Camargo ${ }^{3}$, Fellype Rodrigo Barroso Costa ${ }^{4}$, José Sérgio Baima Magalhães ${ }^{5}$, Verônica Gaspar Martins Leite de Melo ${ }^{6}$

\begin{abstract}
The Baixo Jaguaribe basin has the smallest area of that Watershed (upper, middle and lower Jaguaribe river), but it has enormous importance in terms of water resources. The amount of water for crops irrigation is quite representative in relation to the total volume of water demanded in the entire Jaguaribe river basin. The research presents a methodology of indicators and criteria to define the priority of use of irrigation water in conditions of water scarcity. The analysis of four requirements of socioeconomic security (productive, economic, water and social) indicated a recommendation to cultivate tomato, forage palm, melon, cassava and papaya, that required the smallest water cuts for irrigation at the River Basin (less than 21\%). However, crops as orange, rice, soursop, coconut, lemon, custard apple, guava, mango, banana and sugarcane must present the highest water cuts (more than 37\%), mainly orange, rice, soursop, coconut, lemon and custard apple which may present values higher than $46 \%$ due to their low profitability and yield, and high water consumption.
\end{abstract}

Keywords: Productive security, water security, economic security, social security, water demand

\section{INDICADORES E CRITÉRIOS PARA DEFINIR A PRIORIDADE NO USO DA ÁGUA DE IRRIGAÇÃO NA BACIA DO BAIXO JAGUARIBE, BRASIL}

\section{RESUMO}

Embora a bacia do Baixo Jaguaribe seja a de menor área de todas as bacias do rio Jaguaribe (Alto, Médio e Baixo Jaguaribe), ela apresenta grande importância no contexto dos recursos hídricos A quantidade de água para irrigação é bastante representativa em relação ao volume total de água demandado em toda a bacia do rio Jaguaribe. A pesquisa apresenta uma metodologia de indicadores

\footnotetext{
${ }^{1}$ Full Professor, ESALQ/USP, Research Fellow FUNCAP - Fortaleza, CE. Email: frizzone@ usp.br

${ }^{2}$ D.Sc. - Executive Secretary for Agribusiness - SEDET, CE - Fortaleza, CE. Email: silviocarlos@yahoo.com.br

${ }^{3}$ D.Sc., Irrigation Specialist - Santa Colomba Agropecuária LTD - Cocos, BA. Email: debora_dcc@yahoo.com.br

${ }^{4}$ D.Sc - INOVAGRI Researcher - Fortaleza, CE. Email: fellype.rodrigo@ hotmail.com

${ }^{5}$ Agronomist - Project Specialist at ADECE - Fortaleza, CE. Email: sergiobaima@yahoo.com.br

${ }^{6}$ Agronomist, - Master's stud. in Agric. Syst. Eng. ESALQ/USP - Piracicaba, SP. Email: vgaspar.vg@ gmail.com
} 
e de critérios para definir a prioridade de uso da água de irrigação em condições de escassez hídrica. A análise de quatro quesitos de segurança socioeconômica (seguranças produtiva, econômica, hídrica e social) indicou que é recomendável cultivar tomate, palma, melão, macaxeira e mamão, requerendo-se, neste caso, os menores cortes hídricos para irrigação na bacia (inferior a 21\%). Já os cultivos de laranja, arroz, graviola, coco, limão, ata, goiaba, manga, banana e cana-de-açúcar devem sofrer os maiores corte hídricos (superior a 37\%), destacando-se as culturas de laranja, arroz, graviola, coco, limão e ata com cortes hídricos sugeridos superiores a $46 \%$, pelas baixas rentabilidades, produtividades e elevados consumos hídricos.

Palavras-chave: Segurança produtiva, segurança hídrica, segurança econômica, segurança social, demanda de água

\section{INTRODUCTION}

The growing scarcity of water and the increase in its cost led to the perception that water should be allocated and used more efficiently (LEVIDOW et al., 2014; LEIBUNDGUT; KHON, 2014). The consensus, at least among economists, is that this is best done through demand management and treating water as an economic factor (GRAFTON et al., 2018). Markets and prices can be used to help ensure usage, minimize waste, ensure efficient allocation and provide incentives for the development of waterefficient technologies, reuse and recycling (LEVIDOW et al., 2014).

Improving the management of water resources in agriculture is a priority objective worldwide, especially in semiarid territories such as the Brazilian Northeast. One of the biggest challenges in the near future will be to increase food production using less water, particularly in countries with limited water resources. In irrigated areas, the new management strategy should be based on achieving maximum gross margins, considering the sustainable use of resources, without necessarily reaching the maximum yield (CÓRCOLES et al., 2010; CÓRCOLES et al., 2016; ANGELAKIS et al., 2020).

The increase in water use may result in restrictions on its availability for use on irrigated land. In addition, the scarcity of water, typical of arid and semi-arid regions, together with a tendency to increase production costs (for example, with seeds, fertilizers and energy), establish uncertainties about the viability of irrigated agriculture, that is related to development. One of the most important characteristics of irrigated agriculture is that it must be sustainable to guarantee its viability (CÓRCOLES et al., 2012; MATEOS et al, 2018).

In recent years, the Brazilian government has made several improvements in irrigated agriculture, such as investment in new hydraulic installations and rehabilitation of older systems. In irrigation districts, the system's efficiency performance is not high, possibly not only due to hydraulic distribution facilities (MATEOS et al., 2018), but also for the inappropriate management of irrigation. It is important to analyze the performance of the irrigation system due to the high investment. One way to improve the management of scarce water resources is to increase the efficiency of water use, making investments in knowledge and human training.

Historically, water scarcity in the Ceará State was justified only by eminently climatic conditions. However, it is no longer exclusively a natural factor but also a consequence of the growing demand for multiple uses, among which irrigated agriculture, tourism, population growth and industry, dependent on large amounts of water (ADECE, 2017).

In order to optimize the management of water resources in the State of Ceará, the need became to develop tools based on decisionmaking processes, capable of contributing to better planning and management of water resources, with the purpose of contributing to the improvement and definition of water management strategies public management, within the State's socioeconomic interests. 
The use of indicators for the assessment will enable the improvement of water resources management and its dependent public policies, considering, in addition to aspects intrinsically related to supply, economic, social and environmental aspects.

The Baixo Jaguaribe Basin is the smallest area in the three Jaguaribe Watershed (upper, middle and lower Jaguaribe River), presenting great importance in the context of water resources, as its water demand for irrigation of agricultural crops is $198,936,594 \mathrm{~m}^{3}, \quad$ corresponding to approximately $47 \%$ of the total volume of water demanded in the Jaguaribe Basin (INESP, 2009).

The objective of this work is to develop socioeconomic indicators for the irrigated areas in the Baixo Jaguaribe Basin - CE, which, together, will allow analyzing the use of water in the irrigation of crops in this region, with a view to improving decision making in relation to management and allocation of water for irrigation in situations of water scarcity.

\section{METHODOLOGY}

The Baixo Jaguaribe Basin has a drainage area of $6,875 \mathrm{~km}^{2}$, covering approximately $137 \mathrm{~km}$, which extends from the Peixe Gordo Bridge to its outfall, in the city of Fortim (MOREIRA, 2013). That watershed has as main tributary the Palhano River, where the Santo Antônio de Russas reservoir (capacity of $24,000,000 \mathrm{~m}^{3}$ ) is located, the only reservoir in this region managed by the Water Resources Management Company (COGERH). In this basin are included 9 municipalities: Aracati, Fortim, Icaupí, Itaiçaba, Jaguaruana, Limoeiro do Norte, Quixeré, Russas and Tabuleiro do Norte. The Baixo Jaguaribe Basin presents heterogeneity in the space-time distribution of rainfall, with different characteristics for the municipalities that compose it. The hot semiarid and sub-humid climate provides average annual temperatures around $26^{\circ} \mathrm{C}$ to $28^{\circ} \mathrm{C}$. The annual rainfall average of the River Basin is $838.0 \mathrm{~mm}$ (INESP, 2009).

The average annual precipitation for each municipality indicates rainfall variability for the region, from $707 \mathrm{~mm}$ for the municipality of Palhano to $1,435 \mathrm{~mm}$ for Fortim, while the average annual reference evapotranspiration varies from $1,611 \mathrm{~mm}$ in Fortim to $1,933 \mathrm{~mm}$ in Limoeiro do Norte (INESP, 2009). The rainy season is from February to May and the dry season in other months.

The municipalities with the greatest influence in the Baixo Jaguaribe basin are Limoeiro do Norte, with 7,136 ha which is irrigated with banana predominance (2,130 ha); Jaguaruana, with 4,749 ha irrigated with a predominance of sugar cane $(1,800 \mathrm{ha})$ and rice (1,603 ha); Quixeré with 4,311 ha irrigated with banana predominance $(2,262 \mathrm{ha})$ and Russas with 3,884 ha irrigated with banana predominance $(1,183$ ha) (ADECE, 2018). Socioeconomic indicators are important parameters to have a perspective of the influence of production, revenue, water consumption and job creation of irrigated crops in the Baixo Jaguaribe Basin.

To analyze the performance of irrigated crops in this watershed, socioeconomic performance indicators were used, grouped into four items, each composed of two indicators (Table 1): (a) productive security: land productivity $\left(\mathrm{kg} \mathrm{ha} \mathrm{ha}^{-1}\right)$ and water productivity $\left(\mathrm{kg} \mathrm{m}^{-3}\right)$, (b) economic security: profitability per unit area $\left(\mathrm{R} \$ \mathrm{ha}^{-1}\right)$, and profitability by quantity of applied water $\left(\mathrm{R} \$ \mathrm{~m}^{-3}\right)$, (c) social security: number of jobs generated per unit area (jobs $\left.\mathrm{ha}^{-1}\right)$, and jobs per unit volume of water applied (jobs $\mathrm{m}^{-3}$ ), and (d) water security: amount of water used for irrigation per unit area, $\left(\mathrm{m}^{3} \mathrm{ha}^{-1}\right)$, and time of the crop cycle. After analyzing the requirements and defining the weights applied to the indicators, the water cut was calculated, allowing to define which crops would have the highest priority in the event of water scarcity. 
Table 1. Analysis requirements for the demanding sector and water allocation in conditions of water restriction and the respective indicators to which they relate

\begin{tabular}{lcc}
\hline Item & Indicator 1 & Indicator 2 \\
\hline Productivity Security & $\mathrm{kg} \mathrm{ha}^{-1}$ & $\mathrm{~kg} \mathrm{~m}^{-3}$ \\
Economic Security & $\mathrm{R} \$ \mathrm{ha}^{-1}$ & $\mathrm{R} \$ \mathrm{~m}^{-3}$ \\
Social Security & $\mathrm{Jobs} \mathrm{ha}^{-1}$ & $\mathrm{Jobs} \mathrm{m}$ \\
Water Security & $\mathrm{m}^{3} \mathrm{ha}^{-1}$ & Crop Cycle \\
\hline
\end{tabular}

The indicators were applied in the irrigated agriculture sector of the Baixo Jaguaribe Basin. Three weight levels (high, medium and low) were used in each of the indicators. In this work, the indicators of productive, economic and social security were valued as follows: (a) high weight $=1.00$; (b) average weight $=0.75$; and (c) low weight $=$ 0.50 . It is noteworthy that these weights were assigned arbitrarily, being possible to change them according to need and common sense, since they are input data for the model.

The issue of water security received a reverse valuation, as the indicators analyze the highest water use in the demanding sector. Thus, the high weight should receive the lowest value, that is: High weight $=0.50$; average weight $=0.75$, and low weight $=1.00$. For each of the four items analyzed, criteria were used to apply the weight levels:

(a) Productive security : Indicator $\mathrm{Kg} \mathrm{ha}^{-1}$ :

- if the productivity of the land is $\geq$ the maximum regional productivity of the land, the High weight $=1.00$ is used;

- if the productivity of the land is between the maximum regional productivity of the land and $70 \%$ of its value, the average weight $=0.75$ is used;

- if the land productivity is below $70 \%$ of the regional land productivity, the Low weight $=0.50$ is used.

Indicator $\mathrm{kg} \mathrm{m}^{-3}$ :

- If the productivity of the land is $\geq$ the maximum productivity of the regional land, the High weight $=1.00$ is used;

- - If the productivity of the land is between the maximum productivity of the regional land and $70 \%$ of its value, the Average weight $=0.75$ is used;

- - If the land productivity is below $70 \%$ of the regional land productivity, the Low weight $=0.50$ is used. (b) Economy Security: Indicator $\mathrm{R} \$ \mathrm{ha}^{-1}$ :

- - if the unitary net profit is $\geq$ the maximum regional unitary net profit, the weight High $=1.00$ is used;

- - if the unitary net profit is between the maximum regional unitary net profit and $70 \%$ of its value, the average weight $=$ 0.75 is used;

- - if the unitary net profit is below $70 \%$ of the maximum regional unitary net profit, the Low weight $=0.50$ is used.

Indicator $\mathrm{R} \$ \mathrm{~m}^{-3}$ :

- - if the unitary net profit is $\geq$ the maximum regional unitary net profit, the weight High $=1.00$ is used;

- - if the unitary net revenue is between the maximum regional unitary net revenue and $70 \%$ of its value, the average weight $=$ 0.75 is used;

- - if the unitary net profit is below $70 \%$ of the maximum regional unitary net profit, the Low weight $=0.50$ is used.

(c) Social Security: Indicator job ha-1:

- - if the number of employees per ha is $\geq$ the maximum number of employees per regional hectare, the weight High $=1.00$ is used;

- if the number of employees per hectare is between the maximum number of employees per regional hectare and $70 \%$ of its value, the average weight $=0.75$ is used;

- if the number of employees per hectare is below $70 \%$ of the maximum number of employees per regional hectare, the Low weight $=0.50$ is used.

Indicator jobs $\mathrm{m}^{-3}$ :

- if the number of employees per hectare is $\geq$ the maximum number of employees per regional hectare, the weight High = 1.00 is used; 
- if the number of employees per hectare is between the maximum number of employees per regional hectare and $70 \%$ of its value, the average weight $=0.75$ is used;

- if the number of employees per hectare is below $70 \%$ of the maximum number of employees per regional hectare, the Low weight $=0.50$ is used.

(d) Water Security: Indicator $\mathrm{m}^{3} \mathrm{ha}^{-1}$ :

- if the actual water consumption is $\geq 1.3 \%$ of the ideal water consumption, the weight High (high consumption) $=0.50$ is used;

- - if the actual water consumption is between the ideal water consumption and 1.3 of its value, the average weight $=0.75$ is used;

- if the actual water consumption is below the ideal water consumption, the Low weight (low consumption) $=1.00$ is used .

\section{Indicator Crop Cycle:}

- - if the crop is permanent, High weight (high consumption) $=0.50$ is used;

- - if the crop has a long temporary cycle (over 180 days), Average weight $=0.75$ is used;

- - if the crop has a short temporary cycle (below 180 days), Low weight (low consumption) $=1.00$ is used.

The irrigated area, production and recipe information used in this work were obtained from the IBGE (2018), database with the exception of the forage palm, whose data used were obtained in the field. The amount of jobs generated and the actual amount of water used by activities in the River Basin were obtained from the ADECE (2018) database. The ideal water consumption by the activities was calculated by the S@I system (LIMA et al., 2015), which was the Decision Support System (SSD) chosen to perform the calculations of the indicators of each crop in the watershed.

For the calculation of crop evapotranspiration by the S@I system, data from meteorological stations belonging to the National Institute of Meteorology (INMET) and the crop coefficient published by FAO (ALLEN et al., 1998) were used. The closest weather station was adopted for each municipality, regardless of whether or not they belonged to the same River Basin. Thus, for the municipalities of Limoeiro do Norte and Tabuleiro do Norte the Morada Nova station was used. The Jaguaruana station was used for the municipalities of Jaguaruna, Itaiçaba, Acarati, Icapuí, Fortim, Russas and Quixeré.

After registering the input data in the S@I system, analyzing the socioeconomic indicators and defining the weights applied to each of the indicators, information on the suggested water cut was generated for each water demanding sector in the basin. For this, a model was used to calculate and weight the applied values by combining weights determined for each sector of analysis. The model makes a weighting of the weight valuation using the Equation (1):

$$
R=\frac{\left(P_{1}+P_{2}\right)+\left(E_{1}+E_{2}\right)+\left(S_{1}+S_{2}\right)+\left(H_{1}+H_{2}\right)}{N}
$$

Of which: P1: weight of the indicator $\mathrm{kg} \mathrm{ha}^{-1} ; \mathrm{P} 2$ : weight of the indicator $\mathrm{kg} \mathrm{m}^{-3} ; \mathrm{E} 1$ : weight of the $\mathrm{R} \$ \mathrm{ha}^{-1}$ indicator; E2: weight of the indicator $\mathrm{R} \$ \mathrm{~m}^{-3}$; $\mathrm{S} 1$ : weight of the indicator jobs ha-1, S2: weight of the jobs indicator $\mathrm{m}^{-3}$; $\mathrm{H} 1$ : weight of the indicator $\mathrm{m}^{3} \mathrm{ha}^{-1} ; \mathrm{H} 2$ : weight of the cultivation cycle indicator; $\mathrm{N}$ : number of indicators used (in this case, $\mathrm{N}=8$ ); $\mathrm{R}$ : weighting result with values between 0 and 1 .

The result of the water cut will be as follows [Equation (2)]:

$$
\% \text { Water Cut }=(\mathrm{R}-1) 100
$$




\section{RESULTS AND DISCUSSION}

Table 2 shows the water demand for crops implanted in the municipalities of the Baixo Jaguaribe Basin. The total volume of water demanded annually by irrigated crops is $211,526,724 \mathrm{~m}^{3}$. It is observed that the municipality of Limoeiro do Norte is the one with the highest annual water demand $\left(64,293,198 \mathrm{~m}^{3}\right)$.

Then comes the municipality of Jaguaruana, with an annual demand of $46,787,151 \mathrm{~m}^{3}$. On the other hand, the municipality of Fortim is the one that demands the lowest annual volume of water $\left(895,008 \mathrm{~m}^{3}\right)$.

Table 2. Classification of municipalities in the Baixo Jaguaribe Basin regarding the annual water demand of the implanted crops (year: 2017)

\begin{tabular}{lccccccc}
\hline \multicolumn{1}{c}{ City } & $\begin{array}{c}\text { AI } \\
(\mathrm{ha})\end{array}$ & $\begin{array}{c}\text { LD } \\
(\mathrm{mm})\end{array}$ & $\begin{array}{c}\text { LM } \\
(\mathrm{mm})\end{array}$ & $\begin{array}{c}\text { LA } \\
(\mathrm{mm})\end{array}$ & $\begin{array}{c}\text { VD } \\
\left(\mathrm{m}^{3}\right)\end{array}$ & $\begin{array}{c}\text { VM } \\
\left(\mathrm{m}^{3}\right)\end{array}$ & $\begin{array}{c}\text { VA } \\
\left(\mathrm{m}^{3}\right)\end{array}$ \\
\hline Limoeiro do Norte & 5,760 & 5.40 & 161.1 & $1,116.2$ & $309,396.1$ & $9,281,883$ & $64,293,198$ \\
Jaguaruana & 5,576 & 4.90 & 146.3 & 839.1 & $271,841.3$ & $8,155,239$ & $46,787,151$ \\
Quixeré & 2,387 & 5.20 & 156.2 & $1,204.2$ & $124,315.1$ & $3,729,453$ & $28,744,782$ \\
Russas & 1,843 & 4.80 & 144.0 & $1,130.0$ & $88,479.0$ & $2,654,370$ & $20,826,285$ \\
Aracati & 1,707 & 4.70 & 141.4 & 830.9 & $80,442.9$ & $2,413,287$ & $14,183,136$ \\
Icapuí & 1,498 & 4.50 & 136.5 & 847.9 & $68,138.8$ & $2,044,164$ & $12,701,832$ \\
Tabuleiro do Norte & 456 & 5.50 & 163.7 & $1,242.3$ & $24,878.6$ & 746,358 & $5,664,894$ \\
Itaiçaba & 612 & 4.70 & 140.3 & 790.9 & $28,613.1$ & 858,393 & $4,840,308$ \\
Fortim & 135 & 4.20 & 127.2 & 663.0 & $5,725.5$ & 171,765 & 895,008 \\
\hline TOTAL & 19,974 & 5.00 & 150.5 & 996.0 & $1,001,830.4$ & $30,054,912$ & $198,936,594$ \\
\hline AI - & & & & & &
\end{tabular}

AI - irrigated area; LD - daily water demanded; LM - monthly water demanded; LA - annual water demanded; VD - daily water volume demanded; VM - monthly water volume demanded; VA - annual water volume demanded.

Table 3 shows the maximum values of the security indicators for the Baixo Jaguaribe Basin.

For productive security, it is observed that the cultivation of forage palm has the highest productivity values of the land $\left(250,000 \mathrm{~kg} \mathrm{ha}^{-1}\right)$. On the other hand, cocoa and pitaya crops, among all the crops found in this River Basin, showed low productivity per irrigated area $\left(3,000 \mathrm{~kg} \mathrm{ha}^{-1}\right)$.

Table 3. Irrigated crops in the Baixo Jaguaribe Basin and the maximum values of the analyzed criteria.

\begin{tabular}{|c|c|c|c|c|c|c|c|}
\hline \multirow{2}{*}{ Crops } & \multicolumn{2}{|c|}{ Productivity } & \multicolumn{2}{|c|}{ Profitability } & \multirow{2}{*}{$\begin{array}{c}\text { Water } \\
\text { consumption } \\
\left(\mathrm{m}^{3} \mathrm{ha}^{-1}\right) \\
\end{array}$} & \multicolumn{2}{|c|}{ Jobs generated } \\
\hline & $\mathrm{kg} \mathrm{ha}^{-1}$ & $\mathrm{~kg} \mathrm{~m}^{-3}$ & $\mathrm{R} \$ \mathrm{ha}^{-1}$ & $\mathrm{R} \$ \mathrm{~m}^{-3}$ & & $\begin{array}{c}\text { Jobs per } \\
\text { ha }\end{array}$ & $\begin{array}{l}\text { Jobs per } \\
1000 \mathrm{~m}^{3}\end{array}$ \\
\hline Palm & 250,000 & 45.45 & 40,727 & 1.86 & 5,500 & 0.80 & 0.15 \\
\hline Corn & 29,407 & 2.45 & 7,757 & 0.65 & 12,000 & 0.88 & 0.11 \\
\hline Tomato & 89,750 & 8.98 & 69,168 & 6.92 & 10,000 & 3.18 & 0.32 \\
\hline Papaya & 79,785 & 5.32 & 42,001 & 2.80 & 15,000 & 0.55 & 0.04 \\
\hline Melon & 76,518 & 6.96 & 22,253 & 2.55 & 11,000 & 0.72 & 0.07 \\
\hline Watermelon & 73,000 & 6.08 & 3,917 & 0.33 & 12,000 & 0.72 & 0.06 \\
\hline Sugar cane & 64,000 & 3.37 & 3,350 & 0.18 & 19,000 & 0.16 & 0.01 \\
\hline Coconuts & 20,706 & 1.38 & 7,821 & 0.52 & 15,000 & 0.25 & 0.02 \\
\hline Grape & 10,545 & 0.60 & 26,785 & 1.52 & 17,600 & 2.25 & 0.13 \\
\hline Guava & 15,625 & 1.04 & 18,909 & 1.26 & 15,000 & 0.54 & 0.04 \\
\hline Banana & 23,807 & 1.32 & 21,627 & 1.19 & 18,000 & 0.51 & 0.03 \\
\hline Cassava & 23,000 & 3.19 & 16,293 & 2.26 & 7,200 & 0.56 & 0.08 \\
\hline Passion fruit & 28,667 & 2.05 & 75,700 & 5.41 & 14,000 & 0.40 & 0.03 \\
\hline Barbados cherry & 26,325 & 1.46 & 11,047 & 0.61 & 18,000 & 1.76 & 0.10 \\
\hline
\end{tabular}



THE BAIXO JAGUARIBE BASIN, BRAZIL

\begin{tabular}{lccccccc}
\hline Sweet potato & 10,485 & 1.98 & 12,494 & 2.36 & 10,485 & 1.24 & 0.23 \\
Mango & 13,100 & 0.94 & 15,445 & 1.10 & 14,000 & 0.44 & 0.03 \\
Orange & 14,333 & 0.87 & 7,128 & 0.43 & 16,500 & 0.36 & 0.02 \\
Rice & 13,400 & 0.48 & 5,065 & 0.09 & 28,000 & 0.67 & 0.02 \\
Lemon & 12,325 & 0.88 & 6,792 & 0.49 & 14,000 & 0.40 & 0.03 \\
Avocado & 10,200 & 0.54 & 10,404 & 0.55 & 19,000 & 0.81 & 0.04 \\
Soursop & 7,667 & 0.33 & 16,544 & 0.72 & 23,000 & 0.43 & 0.02 \\
Custard apple & 4,400 & 0.42 & 33,440 & 3.17 & 10,536 & 0.58 & 0.06 \\
Cashew & 4,217 & 0.60 & 10,772 & 1.54 & 7,000 & 0.16 & 0.02 \\
Bean & 3,000 & 0.40 & 4,157 & 0.48 & 7,500 & 1.07 & 0.14 \\
\hline
\end{tabular}

Source: Production and employment values were obtained from IBGE (2018). except for production data for sweet potatoes. custard apple and palm that were obtained in the field. Water consumption data for crops and jobs generated were obtained from ADECE (2015). except for sweet potatoes. cassava and lime. which were obtained in the field.

In the Baixo Jaguaribe Basin, forage palm cultivation has the highest productivity values $\left(250,000 \mathrm{~kg} \mathrm{ha}^{-1}\right)$, much higher than other crops, such as tomatoes and papayas, which have productivity of 89,750 and $79,785 \mathrm{~kg} \mathrm{ha}^{-1}$, respectively. In addition to these crops, melon, watermelon and sugar cane stand out, all with values above $60,000 \mathrm{~kg} \mathrm{ha}^{-1}$. On the other hand, the crops of beans, cashews and custard apple were not very productive, all with productivity values below 5,000 $\mathrm{kg} \mathrm{ha}{ }^{-1}$. Regarding water productivity, palm cultivation also had the highest value $\left(45.45 \mathrm{~kg} \mathrm{~m}^{-3}\right)$. Tomato, melon and watermelon crops have intermediate values, greater than $6.0 \mathrm{~kg} \mathrm{~m}^{-3}$. The soursop, beans, lime and rice crops had the lowest water productivity, all with values below $0.50 \mathrm{~kg} \mathrm{~m}^{-3}$. Table 3 reveals low values of water productivity in the Basin, requiring irrigation management practices to increase them.

As for economic security, it is observed that the passion fruit has the best economic yield ( $\mathrm{R} \$ 75,700.00 \mathrm{ha}^{-1}$ ) and, subsequently, the tomato that has a profitability of $\mathrm{R} \$ 69,168 \mathrm{ha}^{-1}$. However, tomatoes have the highest value per unit volume of water applied $\left(\mathrm{R} \$ 6.92 \mathrm{~m}^{-3}\right)$. On the other hand, sugarcane has the lowest profitability per irrigated area $\left(\mathrm{R} \$ 3,350 \mathrm{ha}^{-1}\right)$, while rice has the lowest economic water productivity ( $\mathrm{R} \$ 0.09 \mathrm{~m}^{-3}$ ), indicating that this crop should not have preference for cultivation in the Baixo Jaguaribe Basin.

Regarding to water security in the Basin, it is observed that the rice crop has the highest water consumption per cultivated area $\left(28,000 \mathrm{~m}^{3} \mathrm{ha}^{-1}\right)$, followed by soursop $\left(23,000 \quad \mathrm{~m}^{3} \quad \mathrm{ha}^{-1}\right.$ annually), avocado $\left(19,000 \mathrm{~m}^{3} \quad \mathrm{ha}^{-1}\right)$ and sugar cane $\left(19,000 \mathrm{~m}^{3} \mathrm{ha}^{-1}\right)$. Some crops, such as forage palm, cashew and cassava are more economical in relation to the amount of water consumed, with 5,500, 7,000 and $7,200 \mathrm{~m}^{3} \mathrm{ha}^{-1}$, respectively.

As for social security, it is observed that the tomato crop showed the best result in relation to the amount of jobs generated by irrigated area (3.18 jobs $\left.\mathrm{ha}^{-1}\right)$ and by the amount of water consumed $(0.32$ jobs per $1000 \mathrm{~m}^{3}$ ). On the other hand, sugar cane in the last place, with the lowest amount of jobs generated $\left(0.01\right.$ jobs per $\left.1000 \mathrm{~m}^{3}\right)$.

Table 4 shows the irrigated areas, the daily, monthly and annual water demand for each crop implanted in each municipality in the Baixo Jaguaribe Basin. It is observed that, of the total irrigated area $(19,974$ ha), the banana crop occupies the largest area (4,179 ha) followed by melon (3,929 ha), watermelon $(2,544 \mathrm{ha})$, rice $(1,455 \mathrm{ha})$, coconut (1,105 ha), sugar cane (880 ha), papaya (835 ha) and corn (650 ha). 
Frizzone et al.

Table 4. Daily. monthly and annual water demand for irrigated crops grown in the municipalities of Baixo Jaguaribe (adapted from ADECE. 2018)

\begin{tabular}{|c|c|c|c|c|c|c|c|c|c|}
\hline Municip. & Cultura & $\begin{array}{l}\text { AI } \\
\text { (ha) }\end{array}$ & DI & $\begin{array}{l}\mathrm{LD} \\
(\mathrm{mm})\end{array}$ & $\begin{array}{c}\mathrm{LM} \\
(\mathrm{mm})\end{array}$ & $\begin{array}{c}\text { LA } \\
(\mathrm{mm})\end{array}$ & $\begin{array}{l}\text { VD } \\
\left(\mathrm{m}^{3}\right)\end{array}$ & $\begin{array}{c}\mathrm{VM} \\
\left(\mathrm{m}^{3}\right) \\
\end{array}$ & $\begin{array}{c}\text { VA } \\
\left(\mathrm{m}^{3}\right) \\
\end{array}$ \\
\hline \multirow{14}{*}{ Aracati } & Melon & 880 & 150 & 4.83 & 144.9 & 724.5 & $42,504.0$ & $1,275,120$ & $6,375,600$ \\
\hline & Papaya & 216 & 240 & 4.20 & 126.0 & $1,008.0$ & $9,072.0$ & 272,160 & $2,177,280$ \\
\hline & Watermelon & 240 & 140 & 4.83 & 144.9 & 676.2 & $11,592.0$ & 347,760 & $1,622,880$ \\
\hline & Banana & 83 & 240 & 5.80 & 174.0 & 1.392 .0 & $4,814.0$ & 144,420 & $1,155,360$ \\
\hline & Coconuts & 21 & 240 & 4.10 & 123.0 & 984.0 & 810.6 & 24,318 & 885,600 \\
\hline & Passion fruit & 45 & 240 & 4.83 & 144.9 & $1,159.2$ & $2,173.5$ & 65,205 & 521,640 \\
\hline & Barbados & 40 & 240 & 483 & 1440 & $1150 ?$ & 10320 & 57060 & 463680 \\
\hline & $\begin{array}{l}\text { cherry } \\
\text { Corn }\end{array}$ & $\begin{array}{l}40 \\
40\end{array}$ & $\begin{array}{l}240 \\
180\end{array}$ & $\begin{array}{l}4.83 \\
4.35\end{array}$ & $\begin{array}{l}144.9 \\
130.5\end{array}$ & $\begin{array}{c}1,159.2 \\
783.0\end{array}$ & $\begin{array}{l}1,932.0 \\
1,740.0\end{array}$ & $\begin{array}{l}5 /, 900 \\
52,200\end{array}$ & 313,200 \\
\hline & Guava & 32 & 240 & 3.62 & 108.6 & 868.8 & $1,158.4$ & 34,752 & 278,016 \\
\hline & Cassava & 90 & 240 & 3.86 & 115.8 & 926.4 & $3,690.0$ & 110,700 & 194,544 \\
\hline & Mango & 12 & 240 & 4.83 & 144.9 & $1,159.2$ & 579.6 & 17,388 & 139,104 \\
\hline & Bean & 4 & 180 & 4.59 & 137.7 & 826.2 & 183.6 & 5,508 & 33,048 \\
\hline & Tomato & 4 & 120 & 4.83 & 144.9 & 579.6 & 193.2 & 5,796 & 23,184 \\
\hline & Total & 1,707 & & 4.71 & 141.4 & 830.9 & $80,442.9$ & $2,413,287$ & $14,183,136$ \\
\hline \multirow{8}{*}{ Fortim } & $\begin{array}{c}\text { Coconuts } \\
\text { Barbados }\end{array}$ & 92 & 120 & 4.10 & 123.0 & 492.0 & $3,772.0$ & 113,160 & 452,640 \\
\hline & cherry & 26 & 240 & 4.83 & 144.9 & $1,159.2$ & $1,255.8$ & 37,674 & 301,392 \\
\hline & Guava & 7 & 240 & 3.62 & 108.6 & 868.8 & 253.4 & 7,602 & 60,816 \\
\hline & Cassava & 3 & 240 & 3.86 & 115.8 & 926.4 & 115.8 & 3,474 & 27,792 \\
\hline & Melon & 2 & 180 & 4.83 & 144.9 & 826.2 & 96.6 & 2,898 & 16,524 \\
\hline & Bean & 2 & 150 & 4.59 & 137.7 & 724.5 & 91.8 & 2,754 & 14,490 \\
\hline & Watermelon & 2 & 140 & 4.83 & 144.9 & 676.2 & 96.6 & 2,898 & 13,524 \\
\hline & Sweet potato & 1 & 180 & 4.35 & 130.5 & 783.0 & 43.5 & 1.305 & 7,830 \\
\hline \multirow{12}{*}{ Icapuí } & Total & 135 & & 4.24 & 127.2 & 663.0 & $5,725.5$ & 171,765 & 895,008 \\
\hline & Melon & 640 & 150 & 4.83 & 144.9 & 724.5 & $30,912.0$ & 927,360 & $4,636,800$ \\
\hline & Papaya & 340 & 240 & 4.20 & 126.0 & $1,008.0$ & $14,280.0$ & 428,400 & $3,427,200$ \\
\hline & Coconuts & 264 & 240 & 4.10 & 123.0 & 984.0 & $10,824.0$ & 324,720 & $2,597,760$ \\
\hline & Watermelon & 180 & 140 & 4.83 & 144.9 & 676.2 & $8,694.0$ & 260,820 & $1,217,160$ \\
\hline & Passion fruit & 54 & 240 & 4.83 & 144.9 & $1,159.2$ & $2,608.2$ & 78,246 & 625,968 \\
\hline & Cassava & 10 & 240 & 3.86 & 115.8 & 926.4 & 386.0 & 11,580 & 92,640 \\
\hline & Barbados & & & & & & & & \\
\hline & cherry & 4 & 240 & 4.83 & 144.9 & $1,159.2$ & 193.2 & 5,796 & 46,368 \\
\hline & Guava & 4 & 240 & 3.62 & 108.6 & 868.8 & 144.8 & 4,344 & 34,752 \\
\hline & Lemon & 2 & 240 & 4.83 & 144.9 & $1,159.2$ & 96.6 & 2,898 & 23,184 \\
\hline & Total & 1,498 & & 4.55 & 136.5 & 847.9 & $68,138.8$ & $2,044,164$ & $12,701,832$ \\
\hline \multirow{6}{*}{ Itaiçaba } & Bean & 294 & 180 & 4.59 & 137.7 & 826.2 & $13,494.6$ & 404,838 & $2,429,028$ \\
\hline & Sugar cane & 280 & 150 & 4.83 & 144.9 & 724.5 & $13,524.0$ & 405,720 & $2,028,600$ \\
\hline & Coconuts & 27 & 240 & 4.10 & 123.0 & 984.0 & $1,107.0$ & 33,210 & 265,680 \\
\hline & Soursop & 6 & 240 & 4.10 & 123.0 & 984.0 & 246.0 & 7,380 & 59,040 \\
\hline & Orange & 3 & 240 & 4.83 & 144.9 & $1,159.2$ & 144.9 & 4,347 & 34,776 \\
\hline & $\begin{array}{l}\text { Barbados } \\
\text { cherry }\end{array}$ & 2 & 240 & 4.83 & 144.9 & $1,159.2$ & 96.6 & 2,898 & 23,184 \\
\hline \multirow{11}{*}{ Jaguaruana } & Total & 612 & & 4.68 & 140.3 & 790.9 & $28,613.1$ & 858,393 & $4,840,308$ \\
\hline & Watermelon & 1,920 & 140 & 4.83 & 144.9 & 676.2 & $92,736.0$ & $2,782,080$ & $12,983,040$ \\
\hline & Melon & 1,507 & 150 & 4.83 & 144.9 & 724.5 & $72,788.1$ & $2,183,643$ & $10,918,215$ \\
\hline & Rice & 740 & 240 & 5.31 & 159.3 & $1,274.4$ & $39,294.0$ & $1,178,820$ & $9,430,560$ \\
\hline & Sugar cane & 600 & 150 & 4.83 & 144.9 & 724.5 & $28,980.0$ & 869,400 & $4,347,000$ \\
\hline & Barbados & & & & & & & & \\
\hline & cherry & 210 & 240 & 4.83 & 144.9 & $1,159.2$ & $10,143.0$ & 304,290 & $2,434,320$ \\
\hline & Mango & 203 & 240 & 4.83 & 144.9 & $1,159.2$ & $9,804.9$ & 294,147 & $2,353,176$ \\
\hline & Orange & 126 & 240 & 4.83 & 144.9 & $1,159.2$ & $6,085.8$ & 182,574 & $1,460,592$ \\
\hline & Banana & 83 & 240 & 5.80 & 174.0 & $1,392.0$ & $4,814.0$ & 144,420 & $1,155,360$ \\
\hline & Guava & 114 & 240 & 3.62 & 108.6 & 868.8 & $4,126.8$ & 123,804 & 990,432 \\
\hline
\end{tabular}



THE BAIXO JAGUARIBE BASIN, BRAZIL

\begin{tabular}{|c|c|c|c|c|c|c|c|c|c|}
\hline & Coconuts & 48 & 240 & 4.10 & 123.0 & 984.0 & $1,968.0$ & 59,040 & 472,320 \\
\hline & Soursop & 12 & 240 & 4.10 & 123.0 & 984.0 & 492.0 & 14,760 & 118,080 \\
\hline & Bean & 8 & 180 & 4.59 & 137.7 & 826.2 & 367.2 & 11,016 & 66,096 \\
\hline & Lemon & 5 & 240 & 4.83 & 144.9 & $1,159.2$ & 241.5 & 7,245 & 57,960 \\
\hline & Total & 5,576 & & 4.88 & 146.3 & 839.1 & $271,841.3$ & $8,155,239$ & $46,787,151$ \\
\hline \multirow{20}{*}{$\begin{array}{c}\text { Limoeiro } \\
\text { do } \\
\text { Norte }\end{array}$} & Banana & 1,880 & 240 & 6.20 & 186.0 & $1,488.0$ & $116,560.0$ & $3,496,800$ & $27,974,400$ \\
\hline & Bean & 1,200 & 180 & 4.90 & 147.0 & 882.0 & $58,800.0$ & $1,764,000$ & $10,584,000$ \\
\hline & Melon & 900 & 150 & 5.16 & 154.8 & 774.0 & $46,440.0$ & $1,393,200$ & $6,966,000$ \\
\hline & Rice & 500 & 240 & 5.68 & 170.4 & $1,363.2$ & $28,400.0$ & 852,000 & $6,816,000$ \\
\hline & Corn & 600 & 180 & 4.65 & 139.5 & 837.0 & $27,900.0$ & 837,000 & $5,022,000$ \\
\hline & Lemon & 167 & 240 & 5.16 & 154.8 & $1,238.4$ & $8,617.2$ & 258,516 & $2,068,128$ \\
\hline & Coconuts & 133 & 240 & 4.39 & 131.7 & $1,053.6$ & $5,838.7$ & 175,161 & $1,401,288$ \\
\hline & Guava & 112 & 240 & 3.87 & 116.1 & 928.8 & $4,334.4$ & 130,032 & $1,040,256$ \\
\hline & Papaya & 93 & 240 & 4.49 & 134.7 & $1,077.6$ & $4,175.7$ & 125,271 & $1,002,168$ \\
\hline & Watermelon & 100 & 140 & 5.16 & 154.8 & 722.4 & $5,160.0$ & 154,800 & 722,400 \\
\hline & Cassava & 25 & 240 & 4.13 & 123.9 & 991.2 & $1,032.5$ & 30,975 & 247,800 \\
\hline & Mango & 20 & 240 & 4.13 & 123.9 & 991.2 & 826.0 & 24,780 & 198,240 \\
\hline & $\begin{array}{l}\text { Barbados } \\
\text { cherry }\end{array}$ & 6 & 240 & 5.16 & 154.8 & 1.238 .4 & 309.6 & 9.288 & 74.304 \\
\hline & Tomato & 10 & 120 & 5.16 & 154.8 & 619.2 & 516.0 & 15,480 & 61,920 \\
\hline & Custard & & & & & & & & \\
\hline & apple & 5 & 240 & 4.39 & 131.7 & $1,053.6$ & 219.5 & 6,585 & 52,680 \\
\hline & Palma & 6 & 240 & 4.90 & 147.0 & 496.8 & 294.0 & 8,820 & 29,808 \\
\hline & Orange & 2 & 240 & 5.16 & 154.8 & $1,238.4$ & 103.2 & 3,096 & 24,768 \\
\hline & Cashew & 1 & 180 & 3.91 & 117.3 & 703.8 & 39.1 & 1,173 & 7,038 \\
\hline & Total & 5,760 & & 5.37 & 161.1 & $1,116.2$ & $309,396.1$ & $9,281,883$ & $64,293,198$ \\
\hline \multirow{16}{*}{ Quixeré } & Banana & 1,300 & 240 & 5.80 & 174.0 & $1,392.0$ & $75,400.0$ & $2,262,000$ & $18,096,000$ \\
\hline & Coconuts & 310 & 240 & 4.10 & 123.0 & 984.0 & $12,710.0$ & 381,300 & $3,050,400$ \\
\hline & Rice & 155 & 240 & 5.31 & 159.3 & $1,274.4$ & $8,230.5$ & 246,915 & $1,975,320$ \\
\hline & Mango & 142 & 240 & 4.83 & 144.9 & $1,159.2$ & $6,858.6$ & 205,758 & $1,646,064$ \\
\hline & Papaya & 150 & 240 & 4.20 & 126.0 & $1,008.0$ & $6,300.0$ & 189,000 & $1,512,000$ \\
\hline & Bean & 115 & 180 & 4.59 & 137.7 & 826.2 & $5,278.5$ & 158,355 & 950,130 \\
\hline & Watermelon & 100 & 140 & 4.83 & 144.9 & 676.2 & $4,830.0$ & 144,900 & 676,200 \\
\hline & Guava & 60 & 150 & 3.62 & 108.6 & 543.0 & $2,172.0$ & 65,160 & 325,800 \\
\hline & Barbados & & & & & & & & \\
\hline & Cherry & 11 & 240 & 4.83 & 144.9 & $1,159.2$ & 531.3 & 15,939 & 127,512 \\
\hline & Lemon & 10 & 240 & 4.83 & 144.9 & $1,159.2$ & 483.0 & 14,490 & 115,920 \\
\hline & Soursop & 10 & 240 & 4.10 & 123.0 & 984.0 & 410.0 & 12,300 & 98,400 \\
\hline & Corn & 10 & 180 & 4.35 & 130.5 & 783.0 & 435.0 & 13,050 & 78,300 \\
\hline & Tomato & 12 & 120 & 4.83 & 144.9 & 579.6 & 579.6 & 17,388 & 69,552 \\
\hline & Orange & 2 & 240 & 4.83 & 144.9 & $1,159.2$ & 96.6 & 2,898 & 23,184 \\
\hline & Total & 2,387 & & 5.21 & 156.2 & $1,204.2$ & $124,315.1$ & $3,729,453$ & $28,744,782$ \\
\hline \multirow{16}{*}{ Russas } & Banana & 833 & 240 & 5.80 & 174.0 & $1,392.0$ & $48,314.0$ & $1,449,420$ & $11,595,360$ \\
\hline & Guava & 469 & 240 & 3.62 & 108.6 & 868.8 & $16,977.8$ & 509,334 & $4,074,672$ \\
\hline & Coconuts & 210 & 240 & 4.10 & 123.0 & 984.0 & $8,610.0$ & 258,300 & $2,066,400$ \\
\hline & Lemon & 40 & 240 & 4.83 & 144.9 & $1,159.2$ & $1,932.0$ & 57,960 & 463,680 \\
\hline & Orange & 36 & 240 & 4.83 & 144.9 & $1,159.2$ & $1,738.8$ & 52,164 & 417,312 \\
\hline & $\begin{array}{l}\text { Barbados } \\
\text { cherry }\end{array}$ & 34 & & & 1440 & $1150 ?$ & 16422 & 49.266 & 394.128 \\
\hline & Papaya & 36 & 240 & 4.20 & 126.0 & $1,008.0$ & $1,512.0$ & 45,360 & 362,880 \\
\hline & Cashew & 45 & 150 & 3.91 & 117.3 & 586.5 & $1,759.5$ & 52,785 & 263,925 \\
\hline & Rice & 20 & 240 & 5.31 & 159.3 & $1,274.4$ & $1,062.0$ & 31,860 & 254,880 \\
\hline & Cassava & 20 & 240 & 3.83 & 114.9 & 919.2 & 766.0 & 22,980 & 183,840 \\
\hline & Sweet potato & 33 & 120 & 4.35 & 130.5 & 522.0 & $1,435.5$ & 43,065 & 172,260 \\
\hline & Avocado & 15 & 240 & 4.10 & 123.0 & 984.0 & 615.0 & 18,450 & 147,600 \\
\hline & Grape & 11 & 240 & 4.10 & 123.0 & 984.0 & 451.0 & 13,530 & 108,240 \\
\hline & Bean & 8 & 180 & 4.59 & 137.7 & 826.2 & 367.2 & 11,016 & 66,096 \\
\hline & Mango & 5 & 240 & 4.83 & 144.9 & $1,159.2$ & 241.5 & 7,245 & 57,960 \\
\hline & Passion fruit & 5 & 240 & 4.83 & 144.9 & $1,159.2$ & 241.5 & 7,245 & 57,960 \\
\hline
\end{tabular}


Frizzone et al.

\begin{tabular}{clcccccccc}
\hline & Palm & 10 & 240 & 4.59 & 137.7 & 496.8 & 459.0 & 13,770 & 49,680 \\
& Tomato & 8 & 120 & 4.83 & 144.9 & 579.6 & 386.4 & 11,592 & 46,368 \\
& Soursop & 3 & 240 & 4.10 & 123.0 & 984.0 & 123.0 & 3,690 & 29,520 \\
& Watermelon & 2 & 140 & 4.83 & 144.9 & 676.2 & 96.6 & 2,898 & 13,524 \\
\hline & Total & 1,843 & & 4.80 & 144.0 & $1,130.0$ & $88,479.0$ & $2,654,370$ & $20,826,285$ \\
\hline \multirow{6}{*}{ Tabuleiro } & Banana & 180 & 240 & 6.20 & 186.0 & $1,488.0$ & $11,160.0$ & 334,800 & $2,678,400$ \\
do & Lemon & 90 & 240 & 5.17 & 155.1 & $1,240.8$ & $4,653.0$ & 139,590 & $1,116,720$ \\
& Rice & 40 & 240 & 5.68 & 170.4 & $1,363.2$ & $2,272.0$ & 68,160 & 545,280 \\
& Capaya & 30 & 240 & 4.49 & 134.7 & $1,077.6$ & $1,347.0$ & 40,410 & 323,280 \\
& Corn & 33 & 180 & 4.65 & 139.5 & 837.0 & $1,534.5$ & 46,035 & 276,210 \\
& Watermelon & 30 & 140 & 5.17 & 155.1 & 723.8 & $1,551.0$ & 46,530 & 217,140 \\
& Cassava & 20 & 240 & 4.13 & 123.9 & 991.2 & 826.0 & 24,780 & 198,240 \\
& Bean & 20 & 180 & 4.90 & 147.0 & 882.0 & 980.0 & 29,400 & 176,400 \\
& Coconuts & 10 & 240 & 4.39 & 131.7 & $1,053.6$ & 439.0 & 13,170 & 105,360 \\
& Guava & 3 & 240 & 3.87 & 116.1 & 928.8 & 116.1 & 3,483 & 27,864 \\
\hline
\end{tabular}

DI - number of irrigation days.

In the municipalities of Acarati and Icapuí, the crop of melon is the largest demand for water, with an important difference between the other crops. In the municipality of Jaguaruana, watermelon is the crop that demands the most water, followed by melon. In the municipality of Fortim, with the smallest irrigated area among the municipalities, the annual water demand is $895,008 \mathrm{~m}^{3}$, showing the coconut crop with the highest annual water demand $\left(452,640 \mathrm{~m}^{3}\right)$. Itaiçaba has six irrigated crops, consuming an annual volume of 4,840,308 $\mathrm{m}^{3}$. Among them, the crops of beans and sugar cane are those that consume the most water and the crops of orange and barbados cherry are those that consume the least. In Limoeiro do Norte, bananas and beans have the highest annual water demands. In Quixeré, with fourteen irrigated crops, banana and coconut crops are the biggest water users. The municipality of Russas has a wide variety of irrigated crops (22), with banana and guava being the most used water. In Tabuleiro do Norte the greatest need for water occurs for banana cultivation.

Figura 1 shows the results for suggested water cuts for each of the irrigated crops implanted in the Baixo Jaguaribe Basin, in percentage. The priority for water use will be for the crop has the less water cut. Table 5 shows the suggested water cuts, for each of the irrigated crops implanted in the Baixo Jaguaribe Basin, in volume of water used and the area corresponding to the percentage of water cut.

Table 5. Suggested water cut for each irrigated crop implanted in the Baixo Jaguaribe Basin

\begin{tabular}{|c|c|c|c|c|c|c|c|}
\hline \multirow[t]{2}{*}{ Crop } & \multicolumn{3}{|c|}{ Water Cut } & \multirow[t]{2}{*}{ Crop } & \multicolumn{3}{|c|}{ Water Cut } \\
\hline & $\%$ & $\begin{array}{c}\text { Volume } \\
\mathrm{m}^{3}\end{array}$ & $\begin{array}{c}\text { Área } \\
\text { ha }\end{array}$ & & $\%$ & $\begin{array}{c}\text { Volume } \\
\mathrm{m}^{3}\end{array}$ & $\begin{array}{c}\text { Área } \\
\text { ha }\end{array}$ \\
\hline Orange & 50.00 & $1,394,250$ & 84.5 & Sweet potato & 34.00 & 121,206 & 11.6 \\
\hline Rice & 46.00 & $38,060,400$ & $1,359.3$ & Cashew & 34.00 & 109,480 & 15.6 \\
\hline Soursop & 46.00 & 327,980 & 14.3 & Bean & 31.00 & $3,620,025$ & 482.7 \\
\hline Coconuts & 46.00 & $8,183,400$ & 545.6 & Grape & 28.00 & 54.208 & 3.1 \\
\hline Lemon & 46.00 & $2,022,160$ & 144.4 & Passion fruit & 28.00 & 407,680 & 29.1 \\
\hline Custard apple & 46.00 & 24,232 & 2.3 & Corn & 28.00 & $2,294,880$ & 191.2 \\
\hline Guava & 43.00 & $5,179,350$ & 345.3 & Watermelon & 28.00 & $8,648,640$ & 720.7 \\
\hline Mango & 43.00 & $2,299,640$ & 164.3 & Papaya & 21.00 & $2,724,750$ & 181.6 \\
\hline Banana & 40.00 & $31,680,000$ & $1,760.0$ & Cassava & 15.00 & 106,920 & 14.8 \\
\hline Sugar cane & 37.00 & $6,186,400$ & 325.6 & Melon & 12.00 & $2,009,040$ & 182.6 \\
\hline Avocado & 34.00 & 96,900 & 5.1 & Palm & 9.00 & 32,670 & 5.9 \\
\hline Barbados & & & & Tomato & & & \\
\hline cherry & 34.00 & $2,037,960$ & 113.2 & & 6.00 & 20,400 & 2.0 \\
\hline
\end{tabular}




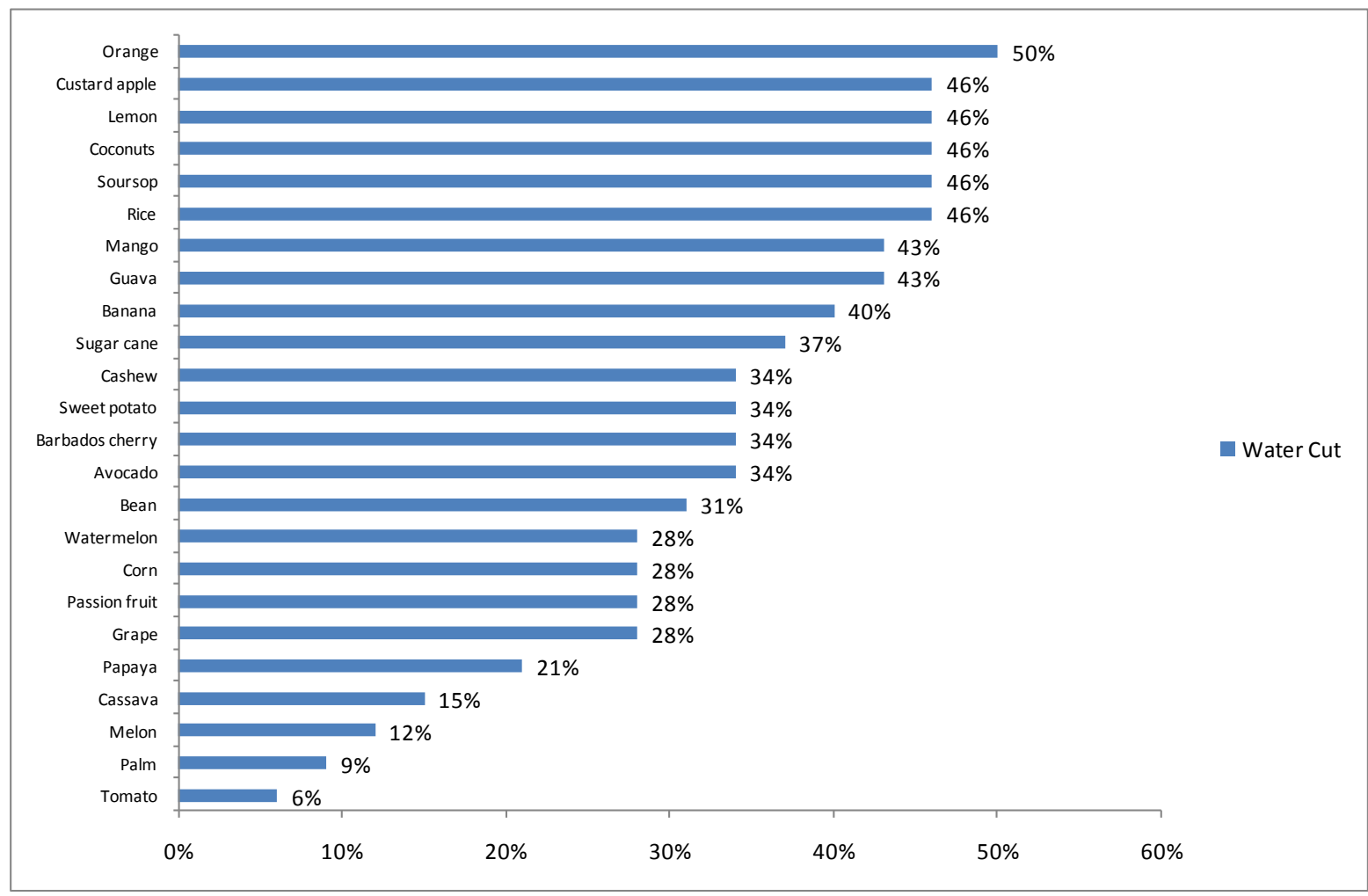

Figura 1. Water cut for each irrigated crop in the Baixo Jaguaribe Basin

In the Baixo Jaguaribe Basin, a 50\% water cut is suggested for the orange crop $\left(1,394,250 \mathrm{~m}^{3}\right)$ or an area reduction of $84.5 \mathrm{ha}$. Following are rice, soursop, coconut, lemon and custard apple crops with $46 \%$ suggested water cut.

Among the crops that would have priority for cultivation in case of water scarcity, are tomatoes, palm and melon, suggesting a water cut of 6,9 and $12 \%$, respectively. In total, the suggested cuts would result in savings of $117,642,571 \mathrm{~m}^{3}$ per year for the Basin, which would correspond to a reduction of 7,843 ha irrigated, if irrigation management is carried out with current consumption.

The results obtained indicate water scarcity and the need to improve the performance of irrigated agriculture in this region. Some options available to improve the sustainability of irrigated agriculture in this River Basin, at the level of the irrigated plot, are: (a) agronomic factors: adopt a cultivation system to improve the use of precipitation or reduce water evaporation; improve soil fertility; improve the soil structure and increase the capacity to store water and nutrients through the incorporation of organic matter; use advanced cultivation strategies that maximize the cultivated area during periods of lower water demand or when rain may be more likely to occur (ALI, et al. 2005; WALLACE and BATCHELOR, 1997); (b) engineering factors: improving the uniformity of irrigation water distribution; use conservation, maintenance and repair programs for irrigation systems and hydraulic structures to reduce the risk of water loss; design wastewater treatment and reuse systems on the farm; modernize and optimize irrigation systems (ALVAREZ et al., 2004; PLAYÁN and MATEOS, 2006); (c) irrigation management factors: promoting irrigation with small to moderate deficits to enable the extraction of deeper water from the soil; perform irrigations at low wind speed times to reduce losses due to evaporation and drift, or use windbreaks; minimize salinity in the root zone of crops (ALI et al., 2008; VAZIFEDOUST et al. 2008); (d) institutional factors: adopt a water pricing system; promote incentives for the efficient use of water and 
penalties for inefficient use; promote user education and training to learn modern irrigation techniques; encourage technical assistance and the dissemination of knowledge (PERRY, et al. 2009); (e) economic factors: reallocating water from crops of lower economic value to crops of greater economic value; when land availability is restricted and water is relatively unrestricted, use irrigation to maximize income per unit area; when water is restricted and the land is relatively unrestricted, irrigate to maximize income per unit volume of water (FRIZZONE, 2004).

\section{CONCLUSIONS}

The research of socioeconomic indicators for irrigated crops, implanted in the Baixo Jaguaribe Basin, has provided the following conclusions for sustainable agriculture in the region:

(a) For better productive security, with regard to physical land productivity $\left(\mathrm{kg} \mathrm{ha}^{-1}\right)$ and physical water productivity $\left(\mathrm{kg} \mathrm{m}^{-3}\right)$, the cultivation of forage palm, tomato, papaya, melon and watermelon is suggested.

(b) For economic security, analyzing the economic productivity of the land $\left(\mathrm{R} \$ \mathrm{ha}^{-1}\right)$, the cultivation of passion fruit, tomato, papaya, palm and lime is suggested; and for better economic productivity of water $\left(\mathrm{R} \$ \mathrm{~m}^{-3}\right)$, tomato, passion fruit, lime, papaya and melon are indicated.

(c) To contribute to the water security of the River Basin, the cultivation of palm, cashew, cassava, beans and tomatoes is suggested, reducing the cultivated areas with rice, soursop, avocado, sugar cane, banana and Barbados cherry. As for the crop cycle, preference should be given to those with a short or medium cycle, avoiding permanent crops to reduce the risk of major losses in the event of water scarcity.

(d) The crops that promote the greatest number of jobs per ha are tomatoes, grapes, Barbados cherry, sweet potatoes and beans; the greatest number of jobs per $\mathrm{m}^{3}$ of water applied was achieved with the cultivation of tomatoes, sweet potatoes, palm, beans and grapes.

(e) The weighting of the four socioeconomic security issues analyzed indicated that, in case of water scarcity, it is recommended to cultivate tomatoes, palm, melon, cassava and papaya, requiring, in this case, the smallest water cuts for irrigation in the basin (less than 21\%). The orange, rice, soursop, coconut, lemon, guava, mango, banana and sugar cane cultivations are expected to suffer the largest water cuts (over $37 \%$ ), especially orange, rice, soursop, coconut, lemon and custard apple with suggested water cuts above $46 \%$, due to low profitability, productivity and high water consumption.

\section{ACKNOWLEDGMENTS}

The author thanks the Ceará Foundation for Support to Scientific and Technological Development (FUNCAP) for the grant fellowship. The research received funding and technical suport from the Development Agency of Ceará - ADECE, the Secretariat of Economic Development and Labor - SEDET, CENTEC Institute and INOVAGRI Institute.

\section{REFERENCES}

ADECE - Agência de Desenvolvimento do Estado do Ceará. Estudo técnico para a alocação de água destinada à irrigação, 130p. 2015. Acessado em 01 de julho de 2018: http://www.adece.ce.gov.br/index.php/agroneg ocio/estudo-das-aguas.

ADECE - Agência de Desenvolvimento do Estado do Ceará. Coeficientes técnicos de mensuração do uso de mão de obra nas culturas irrigadas do Ceará - 2017. 2017.

ADECE - Agência de Desenvolvimento do Estado do Ceará. Estudo para definição de indicadores e critérios de uso da água no setor agropecuário - Estudo das águas: 
Produto V - Indicadores socioeconômicos das áreas irrigadas-05/2018. 2018.

ALI, M.H.; TALUKDER, M.S.U. Increasing water productivity in crop production - A synthesis. Agricultural Water Management, v.95, p.1201 - 1213, 2008.

ALI, M.H., HASSANUZZAMAN, M., BHUIYA, S.H., KHANAM, F. Evaluation of agro-climatic condition for rice cultivation in different regions of Bangladesh. Bangladesh Journal of Environmental Science, v.11, n.1, p.16-21, 2005.

ALLEN, R.G.; PEREIRA, L.S.; RAES, D.; SMITH, M. Crop evapotranspirationguidelines for computing crop water requirements. Roma: FAO, 1998. 300p. (FAO - Irrigation and Drainage Paper, 56).

ALVAREZ, J.F.O; MARTIN-BENITO, J.M.T.; VALERO, J.A.J.; PÉREZ, P.C. Uniformity Distribution and its Economic Effect on Irrigation Management in Semiarid Zones. Journal of Irrigation and Drainage Engineering, v.130, n.4, p.257-268, 2004.

ANGELAKIS, A.N. et al. Irrigation of World Agricultural Lands: Evolution through the Millennia. Water, v.12, n.1285, p.1-50, 2020.

FRIZZONE, J.A. Otimização do uso da água na agricultura irrigada: Perspectivas e desafios. Engenharia Rural, v.15, n.1, p.3756, 2004.

CÓRCOLES，J.I; FRIZZONE，J.A.; LIMA, S.C.R.V.; MATEOS, L.; NEALE, C.M.U.; SNYDER, R.L.; SOUSA, F. Irrigation advisory service and performance indicators in Baixo Acaraú Irrigation District, Brazil. Irrigation and Drainage, v.65, n.1, p.61-72, 2016.

CÓRCOLES，J.I.; JUAN，J.A.; ORTEGA, J.F.; TARJUELO, J.M.; MORENO, M.A. 2012. Evaluation of irrigation systems by using benchmarking techniques. Journal of
Irrigation and Drainage Engineering, v.137, n.3, 225-234. 2012.

CÓRCOLES，J.I.; JUAN， J.A.; ORTEGA, J.F.; TARJUELO, J.M.; MORENO, M.A. Management evaluation of water user associations by using benchmarking techniques. Agricultural Water Management, v.98, n.1, p.1-11, 2010.

GRAFTON, R.Q.; WILLIAMS, C.J.; PERRY, C.J.; MOLLE, F.; RINGLER, C.; STEDUTO; P.; UDALL, B.; WHEELER, S. A.; WHEELER, S.A.; WANG, Y; GARRICK; D.; ALLEN, R.G. The paradox of irrigation efficiency. Science, v.361, n.6404, p.748- 750, 2018.

IBGE - Instituto Brasileiro de Geografia e Estatística. Levantamento Sistemático da Produção Agrícola. Março, 2018.

INESP - Instituto de estudos e pesquisas para o desenvolvimento do estado do Ceará. Caderno regional da sub-bacia do Baixo Juaguaribe. Fortaleza - CE, v.7, 104p., 2009.

LEIBUNDGUT, C.; KHON, I. European traditional irrigation in transition. Part I: Irrigation in times past - A historic land use practice across Europe. Irrigation and Drainage, v.63, p.273-293, 2014.

LEVIDOW, L.; ZACCARIA, D.; MAIA, R.; VIVAS, E.; TODOROVIC, M.; SCARDIGNO, A. Improving water-efficiency irrigation: Prospects and difficulties of innovative practices. Agricultural Water Management, v.146, n.1, p.84-94, 2014.

LIMA, S.C.R.V.; SOUZA, F.; FRIZZONE, J.A.; CAMARGO, DÉBORA COSTA; BELTRÃO JÚNIOR, J.A.; NASCIMENTO, A.K.S. Desempenho do sistema de assessoramento ao irrigante - S@I para a gestão da água em áreas irrigadas: benefícios aos irrigantes e ao distrito. Revista Brasileira de Agricultura Irrigada, v. 9, n.1, p. 1-13, 2015. 
MATEOS, L. ; ALMEIDA, A. C. S.; FRIZZONE, J.A.; LIMA; S.C.R.V. Performance assessment of smallholder irrigation based on an energy-water-yield nexus approach. Agricultural Water Management, v.206, n.2, p.176 - 186, 2018.

MOREIRA, T.M.X. Gestão participativa no Ceará: Análise dos Comitês das Sub-Bacias Hidrográficas do Baixo e Médio Jaguaribe. 2013. 118f. Dissertação (Mestrado Profissionalizante) - Centro de Tecnologia da Universidade federal do Ceará, Fortaleza, CE.

PERRY, C.; STEDUTO, P.; ALLEN, R.G.; BURT, C.M. Increasing productivity in irrigated agriculture: Agronomic constraints and hydrological realities. Agricultural Water Management, v.96, p 1517-1524, 2009.
PLAYÁN, E.; MATEOS, L. Modernization and optimization of irrigation systems to increase water productivity. Agricultural Water Management, v.80, n.2, p.100-116, 2006.

VAZIFEDOUST, M.; VAN DAM, J.C.; FEDDES, R.A,; FEIZI, M. Increasing water productivity of irrigated crop under limited water supply at field scale. Agricultural Water Management, v.95, n.2, p.89-102, 2008.

WALLACE, J. S.; BATCHELOR, C .H. Managing water resources for crop production. Philosophical Transactions of the Royal Society of London-B. Biological Science, v. 352, n. 1356, p.937-947, 1997. 